\title{
Transcriptional Control of Neural Crest Specification into Peripheral Glia
}

\author{
Claire Jacob
}

\begin{abstract}
The neural crest is a transient migratory multipotent cell population that originates from the neural plate border and is formed at the end of gastrulation and during neurulation in vertebrate embryos. These cells give rise to many different cell types of the body such as chondrocytes, smooth muscle cells, endocrine cells, melanocytes, and cells of the peripheral nervous system including different subtypes of neurons and peripheral glia. Acquisition of lineage-specific markers occurs before or during migration and/or at final destination. What are the mechanisms that direct specification of neural crest cells into a specific lineage and how do neural crest cells decide on a specific migration route? Those are fascinating and complex questions that have existed for decades and are still in the research focus of developmental biologists. This review discusses transcriptional events and regulations occurring in neural crest cells and derived lineages, which control specification of peripheral glia, namely Schwann cell precursors that interact with peripheral axons and further differentiate into myelinating or nonmyelinating Schwann cells, satellite cells that remain tightly associated with neuronal cell bodies in sensory and autonomous ganglia, and olfactory ensheathing cells that wrap olfactory axons, both at the periphery in the olfactory mucosa and in the central nervous system in the olfactory bulb. Markers of the different peripheral glia lineages including intermediate multipotent cells such as boundary cap cells, as well as the functions of these specific markers, are also reviewed. Enteric ganglia, another type of peripheral glia, will not be discussed in this review.
\end{abstract}

Key words: neural crest gene regulatory network, cell fate decision, peripheral glia markers

\section{Introduction}

\section{(1)}

he neural crest is at the origin of many tissues in vertebrates. These cells are believed to be an innovation of vertebrates, although hypotheses of evolution from antecedent invertebrate tissues have been proposed (Fritzsch and Northcutt, 1993; Donoghue et al., 2008; Patthey et al., 2014). Furthermore, the neural plate border that gives rise to neural crest cells in vertebrates also exists in some invertebrates. However, the neural crest gene regulatory network is not complete in the invertebrate neural plate border, but interestingly the "missing" genes are expressed in other tissues. This has led to hypothetical scenarios, from which the most likely model is based on the evolution of cis-regulatory elements triggering in the neural plate border expression of genes that are expressed in other tissues in invertebrates (Van Otterloo et al., 2013). Transcriptional control mechanisms are thus key to evolution (Wilson and Odom, 2009), as they are to induce and maintain tissue-specific gene expression during development and in adult organisms.
This review is focused on the transcriptional events and regulations that control the specification of neural crest cells into peripheral glia. I will discuss how the main transcription factors involved in neural crest specification interact and how they are regulated, the different origins of peripheral glia and their specification mechanisms, their potential to change their own fate, and their specific markers.

\section{Neural Crest Gene Regulatory Network}

Neural crest cells originate from the neural plate border that is localized at the interface between the neuroectoderm and the non-neural ectoderm. Combination of Wnt, FGF and BMP signaling induces expression of neural plate border specifiers including the following transcription factors: AP$2 \alpha$, the homeodomain-containing proteins Pax3, Pax7, Msx1, Msx2, Dlx5, Gbx2, and the zinc finger-containing protein Zic1. In addition, FGF-dependent expression of the Xenopus helix-loop-helix transcription factor Hairy2, an ortholog of the mouse Hes1, attenuates BMP signaling and upregulates 


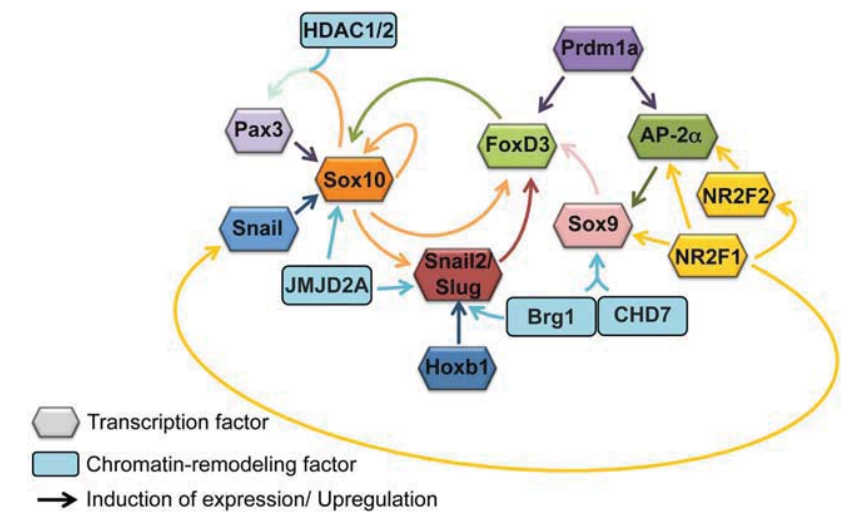

FIGURE 1: Gene regulatory network in the neural crest. A complex network of transcription factors and chromatin-remodeling factors regulates the specification, survival and migration of neural crest cells. The different players of this network synergize to upregulate the expression of Sox10 and FoxD3, two transcription factors critical for peripheral glia specification.

neural plate border genes to maintain cells in an undifferentiated state (Nagatomo and Hashimoto, 2007; Nichane et al., 2008). At the end of gastrulation and during neurulation, neural plate border specifiers synergize to trigger specification of the neural crest (reviewed in Betancur et al., 2010). In particular, Pax3 and Zic1 play a central role: upon Wnt signaling, these two transcription factors are able to recapitulate the sequence of neural crest specifiers expression (Sato et al., 2005; Hong and Saint-Jeannet, 2007; Milet et al., 2013), starting by the early neural crest specifiers Snail, Sox8, and Myc, followed by the intermediate specifiers Sox9 and FoxD3, and finally the late specifiers Slug and Sox10 (Aybar et al., 2003; O'Donnell et al., 2006). In contrast, BMP signaling induces expression of the helix-loop-helix protein Id3, which interacts with Hairy 2 to inhibit its activity and thereby allows the progression into specified neural crest (Nichane et al., 2008). FGF signaling together with attenuated BMP signaling is also able to induce expression of Slug in Xenopus (Mayor et al., 1997; Villanueva et al., 2002). However, studies carried out so far in mouse and zebrafish embryos have not been able to demonstrate absolute requirement of FGF signaling for the specification of the neural crest (Jones and Trainor, 2005).

Loss and gain of function studies in neural crest cells have been mainly carried out in Xenopus, chick, quail, zebrafish, and mouse embryos. These studies revealed a fairly complex network of transcription factor regulations (illustrated in Fig. 1) that converge into expression and upregulation of Sox10 and FoxD3, two key transcription factors for specification, survival and migration of neural crest cells and their derived lineages (Herbarth et al., 1998; Southard-Smith et al., 1998; Britsch et al., 2001; Honoré et al., 2003; Aoki et al., 2003; Stewart et al., 2006; Teng et al., 2008). Although neu- ral crest specifier genes are very well conserved among vertebrates, there are differences. Of note, Snail and Slug originate from a gene duplication, and evolution from a single gene in chordate invertebrates to two genes in vertebrates resulted in different expression patterns among vertebrates: Slug is the only gene expressed in chick embryo neural tube, whereas 3 genes Snail1, Snail2, and Slug are expressed in zebrafish neural tube (Locascio et al., 2002). Furthermore, Snail and Slug are often called Snail1 and Snail2, respectively.

Briefly: Snail, but not Slug, upregulates Sox10 expression (Honoré et al., 2003). In turn, Sox10 induces Slug and FoxD3 (Honoré et al., 2003). Slug and Sox9 upregulate FoxD3 (Nitzan et al., 2013a), and FoxD3 upregulates Snail and Sox10 (Stewart et al., 2006). In chick embryos, anterior Hox genes have been shown to promote neural crest specification. Among those, Hoxb1 upregulates expression of Slug and is the most potent to promote neural crest specification (Gouti et al., 2011). The PR/SET domain-containing transcription factor Prdm1a directly activates expression of FoxD3 and AP- $2 \alpha$ (Powell et al., 2013). In turn, AP-2 $\alpha$ directly activates expression of Sox9 (Luo et al., 2003; Lee et al., 2004; Saint-Germain et al., 2004; Bagheri-Fam et al., 2006). The Sox10 gene possesses several 5 enhancers, which contain many Sox10-binding sites and binding sites for various transcription factors including AP- $2 \alpha$, Sox9, and Pax3 (Werner et al., 2007). Consistent with this, Sox 10 can activate its own expression (Wahlbuhl et al., 2012). In addition, Sox10 maintains expression of Pax3, which in turn synergizes with Sox 10 to upregulate Sox10 levels (Wahlbuhl et al., 2012; Jacob et al., 2014). Finally, a very interesting study using epigenome annotation of enhancers in human neural crest cells allowed the identification of the nuclear receptors NR2F1 and NR2F2 as key transcriptional activators of AP-2 $\alpha$, Sox9, and Snail, and synergistic effects with AP-2 $\alpha$ (Rada-Iglesias et al., 2012).

Negative regulators also play a role to control specification of neural crest cells. Indeed, the BTB domain-containing protein Kctd15 interacts with AP- $2 \alpha$ to inhibit its activity and thereby neural crest formation (Zarelli and Dawid, 2013). The differentiation inhibitor Sox 2 is downregulated as neural crest cells start delaminating from the dorsal neural tube and forced expression of Sox 2 in quail embryos downregulates neural crest specifiers (Wakamatsu et al., 2004a), suggesting that Sox2 needs to be silenced to allow induction of neural crest specification. The DNA methyltransferase DNMT3A plays an essential function in this process by methylating $\mathrm{CpG}$ islands in the Sox2 promoter and thereby repressing its activity (Hu et al., 2012).

To this already intricate network of transcription factors, chromatin-remodelers add another layer of complexity by controlling activity and expression of these neural crest 
specifiers (Fig. 1). Indeed, we recently found that the two highly homologous histone deacetylases (HDACs) 1 and 2 interact with Sox10 to promote the activation of the Pax3 promoter (Jacob et al., 2014). In the absence of HDAC1/2 in neural crest cells of mouse embryos, Sox10 is unable to activate the Pax3 promoter and Pax3 expression is lost (Jacob et al., 2014). The histone demethylase JMJD2A is also critically involved in neural crest gene regulatory network. Ablation of JMJD2A in chick embryos leads to depletion of neural crest specifiers including Sox10, Slug, Sox8, FoxD3, and Wnt1 (Strobl-Mazzulla et al., 2010). Interestingly, this study shows stage-specific binding of JMJD2A to the Sox10 promoter and the Slug promoter, allowing the removal of the repressive histone methylation mark $\mathrm{H} 3 \mathrm{~K} 9 \mathrm{me} 3$ and thereby derepression of these genes at a critical time-point of neural crest specification (Strobl-Mazzulla et al., 2010). Brg1containing (BAF or SWI/SNF) chromatin-remodeling complexes have been also identified to play a role in the regulation of neural crest specification in zebrafish (Eroglu et al., 2006). Indeed, ablation or downregulation of Brg1 in zebrafish embryos leads to decreased expression of neural crest specifiers such as Snail2, AP- $2 \alpha$ and FoxD3 (Eroglu et al., 2006). In this study, the authors show that Brg1 binds to the Snail2 promoter to activate it. However, downregulation of Brg1 in chick embryo neural tube does not prevent Sox10induced expression of the chick neural crest specifier HNK-1 (Weider et al., 2012). Requirement of Brg1 in neural crest specification may thus vary among species. Alternatively, Brg1 may be required to induce Sox10 expression or be more criti$\mathrm{cal}$ at the induction of neural crest specification. In support of the latter hypothesis, the ATP-dependent chromatin remodeling enzyme CHD7 is essential for the formation of neural crest cells by its interaction with Brg1-containing chromatin-remodeling complexes (Bajpai et al., 2010). CHD7/ Brg1 bind to and activate a Sox9 enhancer and a regulatory region of Twist1, another transcription factor expressed in neural crest cells and required for migration and differentiation of the cranial neural crest (Linker et al., 2000; Soo et al., 2002), to induce Sox9 and Twist1 expression, respectively (Bajpai et al., 2010). In support of Brg1-dependent Sox10 expression, $\mathrm{CHD} 7 / \mathrm{Brg} 1$ have been also shown to maintain Sox10 expression in neural crest cell cultures and thereby maintain multipotency (Fujita et al., 2014).

AEBP2, a zinc finger protein that can interact with the mammalian Polycomb Repression Complex 2 (PRC2; Cao and Zhang, 2004), has been reported as a regulator of neural crest specifier genes, potentially through PRC2-mediated H3K27me3 (Kim et al., 2011), but more work is needed to clarify the molecular mechanisms of this regulation. The same is true for the regulation of the Slug promoter by the GLI-Kruppel zinc finger protein YY1, which is required to restrict induction of Slug expression to neural plate border cells (Morgan et al., 2004).

\section{Neural Crest-Derived Peripheral Glia}

Once specified, neural crest cells undergo epithelial-tomesenchymal transition (EMT) and delaminate from the dorsal neural tube (reviewed in Theveneau and Mayor, 2012). They migrate along different routes to reach their final location and they specify or pre-specify into neural crest-derived lineages before, during, and/or after migration. Cells that build the peripheral nervous system (PNS) migrate through dorsal roots to form dorsal root ganglia (DRG), and further to form peripheral nerves and the autonomic nervous system. Among these cells, sensory neurons are the first to be specified (Sommer et al., 1996; Ma et al., 1999). Sensory neurons have a unipolar structure. Their cell body remains localized in the DRG while their central axon extends through the dorsal root into the central nervous system (CNS) and their peripheral axon extends to the peripheral nerve. Schwann cell precursors and satellite cells are specified after sensory neurons (reviewed in Morrison, 2001). Satellite cells migrate through dorsal roots to populate DRG and autonomous ganglia, where they remain tightly associated with neuronal cell bodies, whereas Schwann cell precursors migrate through and out of DRG onto peripheral nerves to interact with and myelinate peripheral axons. Some Schwann cell precursors also remain in dorsal roots to interact with sensory axons before their entry into the CNS, and in ventral roots with motor axons at their exit of the CNS. Dorsal root Schwann cells and a fraction of ventral root Schwann cells and satellite cells originate from intermediate progenitors called boundary cap cells, which also give rise to nociceptive and thermoreceptive neurons at a later stage than the first waves of sensory neurogenesis (Maro et al., 2004; Hjerling-Leffler et al., 2005). In addition to generating PNS cells, boundary cap cells regulate the guidance of sensory and motor axons in and out of the CNS (Golding and Cohen, 1997), and they prevent motor neuronal cell bodies to follow their axon in the PNS (Bron et al., 2007). These cells originate from the neural crest and are localized at the sensory entry and motor exit points, which delineate the boundary between PNS and CNS. To reach the motor exit point, boundary cap cells migrate along the neural tube (Niederländer and Lumsden, 1996). Localization of the different cell types described above, from neural crest cells to peripheral glia, is schematized in Fig. 2.

Olfactory ensheathing cells are another type of glia, which is localized in both PNS and CNS. Indeed, these cells interact with olfactory axons of the olfactory mucosa, and extend to the CNS where they wrap axons of the olfactory bulb. Olfactory ensheathing cells were previously thought to 


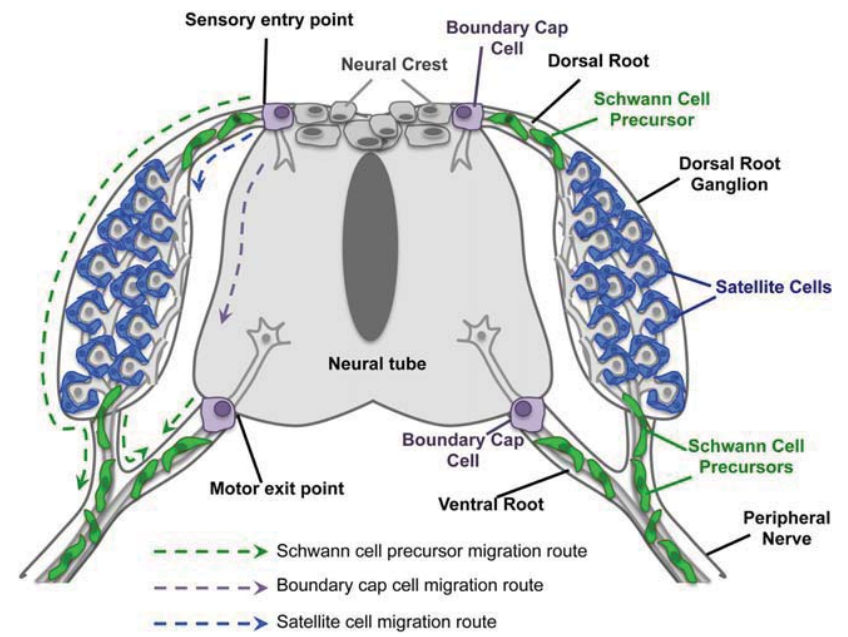

FIGURE 2: Localization and migration routes of peripheral glia. Neural crest cells (gray) delaminate from the dorsal neural tube and migrate into dorsal roots, dorsal root ganglia and peripheral nerves to give rise to sensory neurons (gray), Schwann cell precursors (green), and satellite cells (blue). Intermediate progenitors called boundary cap cells (violet) localize at the dorsal sensory entry point and migrate along the neural tube to also settle at the ventral motor exit point. These cells give rise to all Schwann cell precursors found in the dorsal roots and to a fraction of ventral root Schwann cell precursors, satellite cells, and sensory neurons.

originate, such as olfactory neurons, from the olfactory placode, but recently these cells were shown to actually originate from the neural crest (Barraud et al., 2010; Katoh et al., 2011).

\section{Cell Fate Decision}

There are two waves of peripheral gliogenesis during embryonic development (Fig. 3): distal peripheral nerve Schwann cell precursors and a fraction of ventral nerve root Schwann cell precursors and satellite cells are specified directly from migratory neural crest cells at embryonic day (E) 11 in mice (Morrison, 2001; Jacob et al., 2014). Boundary cap cells that are derived from neural crest cells, are found at E10.5 at the dorsal sensory entry point and the ventral motor exit point, and constitute another source of peripheral glia. Indeed, these cells give rise to all dorsal nerve root and a fraction of ventral nerve root Schwann cell precursors at E11.25 and to a fraction of satellite cells at E12.5 (Maro et al., 2004).

What are the mechanisms that direct specification of neural crest cells into peripheral glia? Although not sufficient on its own, the transcription factor Sox10 is essential (Britsch et al., 2001; Paratore et al., 2001). Sox10 induces expression of the neuregulin-1 receptor ErbB3 and neuregulin-1 activates ErbB3 to favor differentiation into peripheral glia over melanocyte cell fate (Britsch et al., 2001; Adameyko et al., 2009; Prasad et al., 2011). Neuregulin-1 signaling is also required for Schwann cell precursor proliferation and survival (Rieth- macher et al., 1997; Garratt et al., 2000). Sox10 also activates the transcription of the early determinants of peripheral glia fatty acid binding protein 7 (Fabp7) and the glycoprotein P0 (Kurtz et al., 1994; Hagedorn et al., 1999; Peirano et al., 2000; Jessen and Mirsky, 2005; Jacob et al., 2014). However, all neural crest cells express Sox10. Therefore, other mechanisms upstream Sox10 need to control Sox10-induced peripheral glia specification. We recently showed that the two histone deacetylases HDAC1 and HDAC2 interact with Sox10 to activate the Pax3 promoter in neural crest cells. In turn, Pax3 synergizes with Sox 10 to activate the Sox10 MCS4 (Jacob et al., 2014), a 5' enhancer (also called U3) of the Sox10 gene that is critical for Sox 10 expression in neural crest cells (Antonellis et al., 2008; Wahlbuhl et al., 2012). This results in high levels of Sox10 and subsequent activation of the Fabp 7 and PO promoters. We demonstrate that interaction of Sox10 with HDAC1 and HDAC2 is required to activate the $P O$ promoter. Ablation of HDAC1 and $\mathrm{HDAC} 2$ at E10 in mouse neural crest cells leads to loss of Pax3, strongly reduced expression of Sox10 in the DRG and absence of Schwann cell precursors and satellite cells, while other cell types including sensory neurons and smooth muscle cells are specified (Jacob et al., 2014). This mechanism (illustrated in Fig. 4) is thus essential to direct the specification of neural crest cells into peripheral glia.

Notch signaling is also critical for the specification of neural crest cells into peripheral glia. Indeed, exogenous expression of constitutively activated Notch intracellular domain in chick embryo neural tube or the Notch ligand

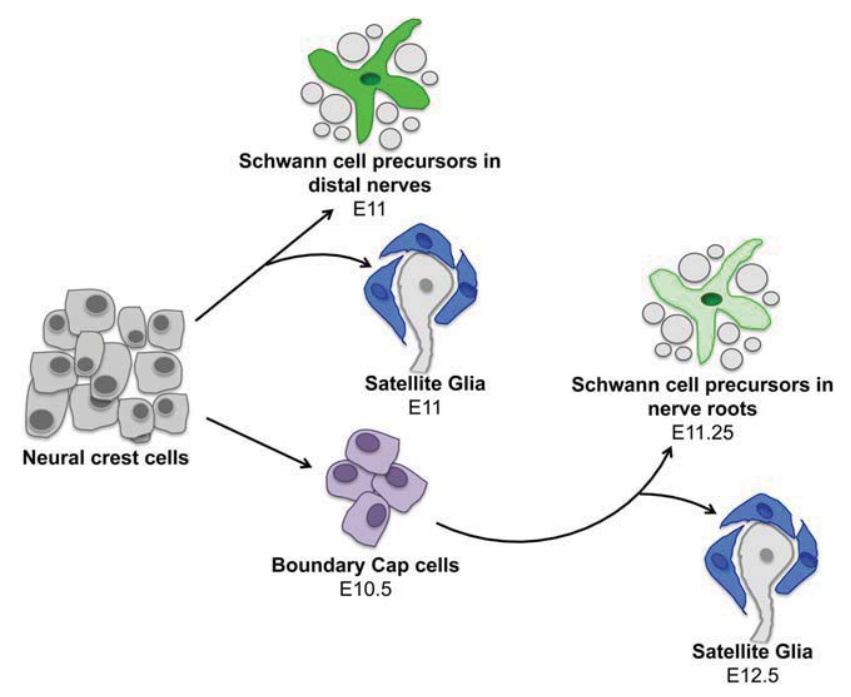

FIGURE 3: Two waves of gliogenesis. The first wave of gliogenesis originates directly from neural crest cells at E11 in mouse embryos. Intermediate multipotent progenitors called boundary cap cells arise from neural crest cells at E10.5. These cells give rise to a second wave of gliogenesis that generates Schwann cell precursors at E11.25 and satellite glia at E12.5 in mouse embryos. 


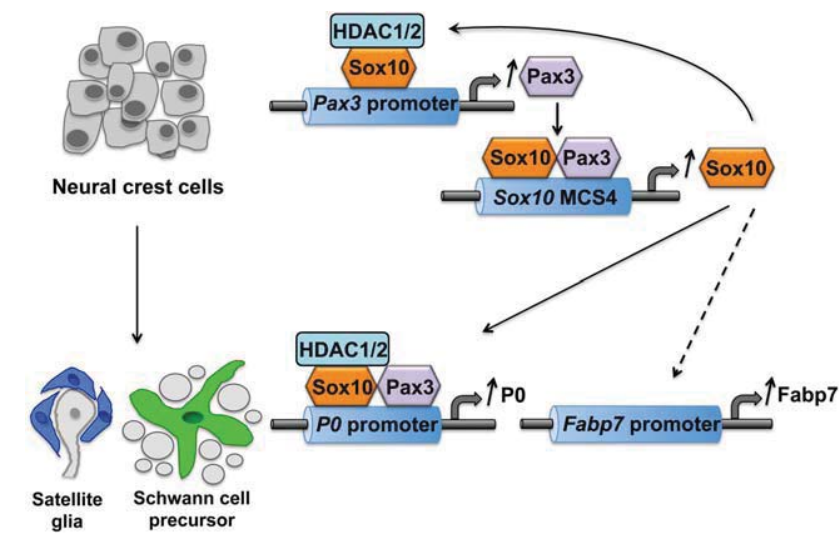

FIGURE 4: Concerted action of HDAC1/2, Pax3 and Sox10 directs neural crest cells into peripheral glia. HDAC1 and HDAC2 (HDAC1/2) interact with Sox10 to activate the Pax3 promoter in neural crest cells. This mechanism allows the maintenance of Pax 3 expression in neural crest cells. Pax3 synergizes with Sox10 to activate the Sox $105^{\prime}$ enhancer MCS4 (also called U3), which is critical for expression of Sox10 in neural crest cells. This leads to maintenance of high Sox10 levels. Subsequently, Sox10 indirectly activates the Fabp7 promoter and interacts with HDAC $1 / 2$ to directly activate the $P O$ promoter. This mechanism is critical to maintain high Sox10 levels and for expression of Fabp7 and P0, two early determinants of peripheral glia.

Delta in neural crest cell culture inhibit neuronal specification and promote specification of peripheral glia (Morrison et al., 2000). In contrast, BMP signaling mediated by BMP-2 or BMP-4 induces neurogenesis (Jones et al., 1991; Shah et al., 1996; Schneider et al., 1999) and represses gliogenesis by triggering expression of the basic helix-loop-helix transcription factor neurogenin-2 (Neurog2), which induces the first wave of sensory neurogenesis at E9.5 in mouse embryos (Sommer et al., 1996; Ma et al., 1999). FGF2 antagonizes this effect by preventing Neurog2 expression and activating Notch signaling (Ota and Ito, 2006). Notch signaling is dominant over BMP signaling, as it can overcome the neuronal differentiation-promoting signal of BMP-2 (Morrison et al., 2000). Canonical Wnt signaling is also required to induce sensory neurogenesis through beta-catenin activation (Hari et al., 2002). Indeed, upon ablation of beta-catenin, neural crest cells emigrate from the neural tube, but are unable to upregulate Neurog 2 and therefore to initiate the first wave of sensory neurogenesis. The second wave of sensory neurogenesis is also impaired in the absence of beta-catenin (Hari et al., 2002; Lee et al., 2004).

The homeodomain transcription factor $\operatorname{Hmx} 1$ is not expressed in migrating neural crest cells, but is exclusively found in Islet1-positive neuroblasts when neural crest cells commit to a neuronal cell fate (Adameyko et al., 2009). Downregulation of Hmx1 by siRNA leads to strong reduction of neurogenesis in favor of Schwann cell precursors and melanocytes. Interestingly, $\mathrm{Hmxl}$ downregulation results in increased number of Schwann cell precursors along spinal nerves, but also in Microphthalmia-associated transcription factor (MITF)-positive melanoblasts migrating between the DRG and the skin. This suggests the existence of a Schwann cell/melanocyte-committed progenitor and the occurrence of melanocyte specification from Schwann cell precursors (Adameyko et al., 2009). Nitzan et al. (2013b) confirmed these findings and further characterized the cell fate switch from Schwann cell precursors to melanocytes. Indeed, they found that the loss of the transcription factor FoxD3 in Schwann cell precursors of peripheral nerves leads to the generation of melanocytes (Nitzan et al., 2013b). Downregulation of FoxD3 in neural crest cells is also necessary for neurogenesis and melanocyte specification, while FoxD3 expression is maintained in peripheral glia (Nitzan et al., 2013a,2013b). Thomas and Erickson (2009) found that FoxD3 does not repress MITF directly in chick embryos, but instead interacts with Pax3 to block Pax3 binding to the Mitf promoter, which prevents MITF expression. However, Ignatius et al. (2008) show in zebrafish embryos that FoxD3 can interact with the Mitf promoter and propose a direct activation of MITF expression by FoxD3. The latter study also identifies HDAC1 as a repressor of FoxD3 expression that is essential for melanogenesis (Ignatius et al., 2008). Nitzan et al. (2013a) also demonstrate that prospective melanoblasts downregulate FoxD3 already in the neural tube before emigration, and that FoxD3 expression marks a population of PNS-committed neural crest cells. If FoxD3 expression is maintained, these intermediate progenitors that retain a similar multipotency as boundary cap cells, will give rise to peripheral glia. Absence of neurogenin-1 (Neurog1) expression will also lead to specification into peripheral glia (McGraw et al., 2008). The proneural transcription factor Neurog1 induces the second wave of sensory neurogenesis (Sommer et al., 1996; Ma et al., 1999) that occurs at E10-E10.5 in mouse embryos, and maybe induces also a later wave derived from boundary cap cells. Interestingly, low levels of Sox10 are required to induce the expression of Neurog1. Therefore, although rapidly downregulated in sensory neurons, Sox10 is necessary at low levels for sensory neurogenesis (Carney et al., 2006).

Finally, the exceptional plasticity of Schwann cell precursors has been highlighted several times last year by studies showing that parasympathetic neurons and some mesenchymal stem cells originate from Schwann cell precursors (Dyachuk et al., 2014; Espinosa-Medina et al., 2014; Kaukua et al., 2014). Authors of these studies show that the parasympathetic neuron fate is induced from Schwann cell precursors that have migrated into distal peripheral nerves. They identify a bipotent progenitor that expresses Sox10 and the panautonomic determinant Phox2B, together with the neural crest markers FoxD3, p $75^{\mathrm{NTR}}$ and the Schwann cell precursor 


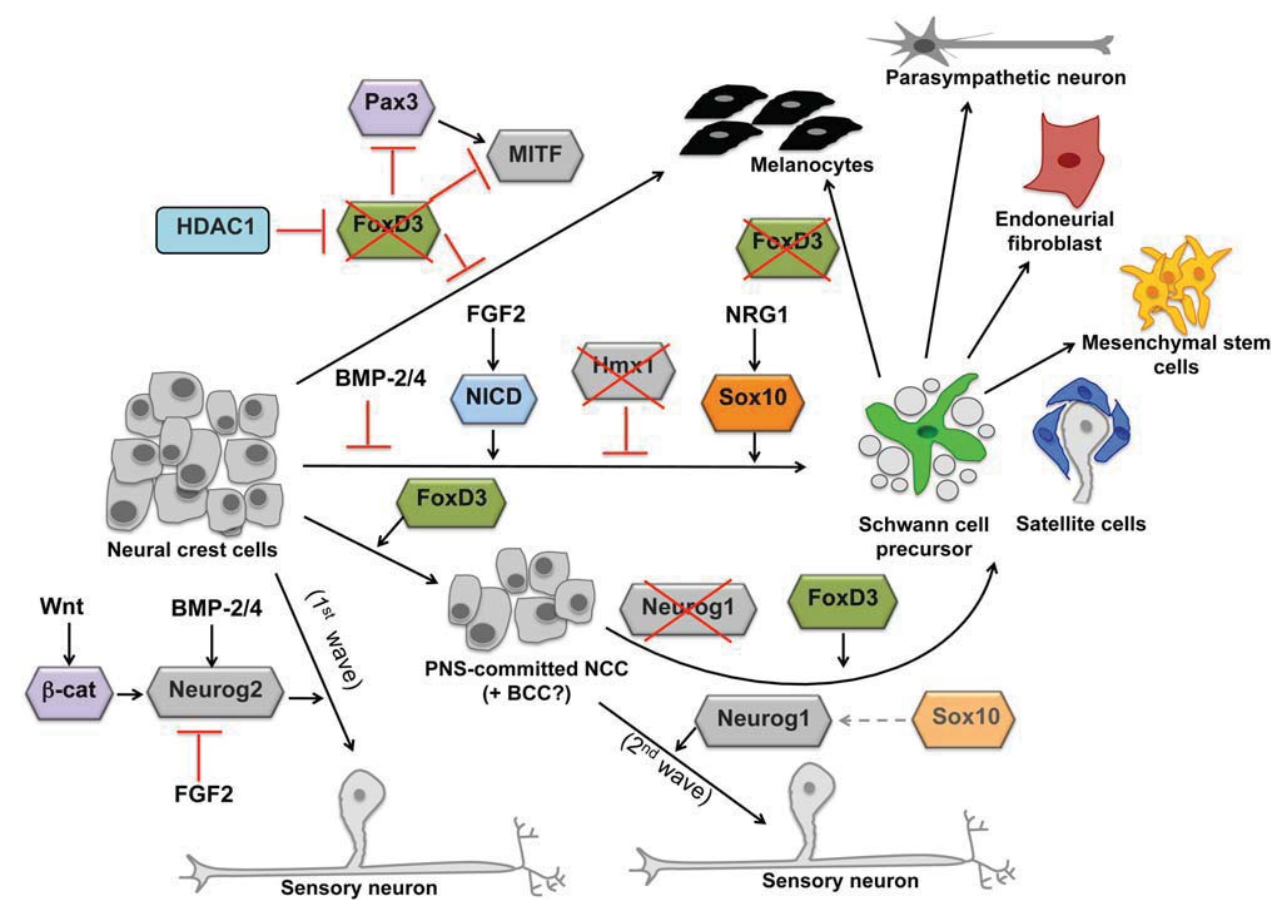

FIGURE 5: Cell fate decision. Wnt, BMP, FGF and neuregulin-1 (NRG1) signaling orchestrate the action of the transcription factors that direct cell fate decision of neural crest cells into either sensory neurons, melanocytes or peripheral glia. The exceptional plasticity of Schwann cell precursors is illustrated here by the ability of these cells to give rise to melanocytes, endoneurial fibroblasts, parasympathetic neurons, and mesenchymal stem cells. The dashed arrow and faded color of Sox10 indicate a requirement of low levels of Sox10 in this mechanism. Abbreviations: NCC: neural crest cells; BCC: boundary cap cells; $\beta$-cat: beta-catenin.

markers ErbB3, Cadherin-19 and PLP. This bipotent progenitor gives rise to Schwann cells after downregulation of Phox2B or maintains Phox2B expression and migrates to the sites of parasympathetic ganglia to adopt a parasympathetic neuron fate (Espinosa-Medina et al., 2014). Kaukua et al. (2014) show that a fraction of mesenchymal stem cells giving rise to pulp cells and odontoblasts originate from Schwann cell precursors associated with peripheral nerves, and hypothesize that other types of mesenchymal stem cells could also be derived from Schwann cell precursors. Interestingly, Hagedorn et al. (1999) demonstrated the existence of post-migratory PNS-committed multipotent cells that express both myelin proteins P0 and PMP22 and can give rise to both neurons and peripheral glia. These findings suggest that expression of P0 in early steps of embryonic development is not an absolute marker of glial fate decision. This has been also suggested in two other studies (Morrison et al., 1999; Joseph et al., 2004). Specifically, Joseph et al. (2004) show that P0expressing intermediate progenitors can give rise to either peripheral glia or endoneurial fibroblasts.

Cell fate decisions and key transcriptional regulators discussed above are illustrated in Fig. 5.

\section{Peripheral Glia Markers and Their Functions}

While neural crest specifiers such as Sox9, Snail, and Slug are downregulated during peripheral glia specification, other ones including Sox10, Pax3, FoxD3, and AP-2 $\alpha$ remain robustly expressed after specification of peripheral glia, at least transiently. Indeed, Sox9 is highly expressed in pre-migratory neural crest cells and although it is required for survival and induction of EMT that precedes migration (Cheung et al., 2005), its expression is downregulated before migration of most neural crest cells, except in the migrating cranial neural crest that populates the pharyngeal arches (Spokony et al., 2002). However, Sox9 mRNA has been detected in purified Schwann cells from E18 embryos and 3-day old rat pups (D'Antonio et al., 2006a), indicating that Sox 9 expression is turned on again, at least at the mRNA level, at later stages of Schwann cell development. As for Snail and Slug, at least one of them (depending on species) is expressed in pre-migratory neural crest cells (Locascio et al., 2002) and synergizes with other transcription factors to induce EMT. However, Snail/Slug need to be downregulated for neural crest cell migration, except in the cranial neural crest where ovexpression of Slug increases the number of both pre-migratory and migratory neural crest cells (Del Barrio and Nieto, 2002). N-cadherin and cadherin 6B are also expressed in pre-migratory neural crest cells, and to allow delamination from the neural tube, a cadherin switch is triggered by the coordinated action of Slug, FoxD3, Sox9, and Sox10: $\mathrm{N}$-cadherin and cadherin $6 \mathrm{~B}$ are downregulated, while other cadherins (7 and 11) are upregulated (reviewed in Theveneau and Mayor, 2012). Interestingly, $\mathrm{N}$-cadherin expression is 
turned on again in sensory neurons and at high level in Schwann cell precursors, where it promotes cell-cell interactions. These interactions allow Schwann cell precursors to build cellular scaffolds that foster nerve compaction and enhance contacts between axons (Wanner et al., 2006). Another cadherin, cadherin-19, has been reported to be specifically expressed in rat Schwann cell precursors, and downregulated as cells further differentiate into immature Schwann cells (Takahashi and Osumi, 2005). Expression has also been shown in rat boundary cap cells (Takahashi and Osumi, 2005). While a transient expression of cadherin-19 in the Schwann cell lineage is supported by cell culture differentiation data (Ziegler et al., 2011), a study in chicken embryos shows that cadherin-19 expression is maintained at later stages of Schwann cell development (Lin et al., 2010). Expression of this marker may thus vary among species. Cadherins are calcium-dependent cell adhesion proteins that connect cells by their homophilic adhesion properties, but a potential specific function of cadherin-19 in peripheral glia development has not yet been demonstrated. The neural cell adhesion molecule L1 regulates cell migration, neurite outgrowth and fasciculation (Fischer et al., 1986), and is expressed in migratory neural crest cells (Shimotake et al., 1995), neurons, satellite cells and Schwann cell precursors, and also at later stages of development in non-myelinating Schwann cells (Faissner et al., 1984; Mirsky et al., 1986). L1 expression, such as NCAM, another neural cell adhesion molecule, is upregulated by TGF-beta, which controls Schwann cell proliferation and apoptosis in vivo (D'Antonio et al., 2002). In cultured Schwann cells, TGF-beta also promotes proliferation, and in addition blocks myelin gene expression (Stewart et al., 1995; Jacob et al., 2008).

Similar to melanocytes, but in contrast to other neuralcrest derived lineages, peripheral glia maintain Sox10 expression after specification (Kuhlbrodt et al., 1998; Britsch et al., 2001; Paratore et al., 2001) and during their entire life. In addition to its central role in peripheral glia specification discussed in the previous section, Sox10 is required for each step of peripheral glia development (Schreiner et al., 2007; Finzsch et al., 2010; Fröb et al., 2012) and for maintenance of peripheral glia differentiation in adult organisms (Bremer et al., 2011). In postnatal Schwann cells, Sox10 activates its own expression and expression of the transcription factor of myelination Krox20 (Ghislain and Charnay, 2006; Finzsch et al., 2010; Reiprich et al., 2010) and the myelin protein P0 (Peirano et al., 2000), in conjunction with the histone deacetylases HDAC1 and HDAC2 (Jacob et al., 2011a). Sox10 also controls expression of the transcription factor of differentiation Oct6 (Finzsch et al., 2010; Jagalur et al., 2011), and of other myelin proteins (Bondurand et al., 2001; Wei et al., 2004). Sox10 is also necessary in boundary cap cells to maintain barrier integrity between CNS and PNS (Fröb et al., 2012).
The neuregulin-1 receptor ErbB3 marks migrating neural crest cells before specification and the entire peripheral glia lineage, while it is downregulated in many other neural crest derived cells (Meyer and Birchmeier, 1995). ErbB3 functions in peripheral glia specification are discussed in the previous section. In peripheral nerves, neuregulin-1/ErbB3 signaling controls radial sorting of big caliber axons in 1:1 relationships with Schwann cells (Taveggia et al., 2005), as well as myelin thickness (Michailov et al., 2004).

Pax3 expression, which is necessary (but not sufficient on its own) for the specification of peripheral glia (Auerbach, 1954; Franz, 1990; Olaopa et al., 2011; Jacob et al., 2014), is maintained in these cells after specification. However Pax3 is also expressed in other neural crest derived lineages, where it plays critical functions (Auerbach, 1954). Pax3 is expressed until E13.5 in mouse Schwann cell precursors and satellite glia. Its expression is then downregulated, but is turned on again in the Schwann cell lineage at later stages, where it has been reported to act as a cell cycle regulator (Kioussi et al., 1995; Doddrell et al., 2012).

FoxD3 and AP-2 $\alpha$ expressions are maintained in peripheral glia after specification and their known functions in this process have been discussed in the previous sections. Interestingly, AP- $2 \alpha$ expression is lost in immature Schwann cells, and can thus be used to discriminate between Schwann cell precursor and immature Schwann cell stages. Consistent with its expression pattern, AP- $2 \alpha$ represses the transition from Schwann cell precursors to immature Schwann cells (Stewart et al., 2001). In addition, this transcription factor is expressed in sympathetic progenitors and differentiated neurons and is required for their survival (Schmidt et al., 2011).

The low-affinity nerve growth factor receptor $\mathrm{p} 75^{\mathrm{NTR}}$ is expressed in neural crest cells and remains expressed in peripheral glia (Jessen et al., 1994), where it promotes apoptosis and thereby regulates cell number by counter-balancing proliferation (Soilu-Hanninen et al., 1999; Syroid et al., 2000). However, ablation of $\mathrm{p} 75^{\mathrm{NTR}}$ does not affect the number of apoptotic cells during normal development, but does after a nerve injury (Syroid et al., 2000; Petratos et al., 2003) indicating that $\mathrm{p} 75^{\mathrm{NTR}}$ may have pro-apoptotic functions only in the case of stress or injury.

In mouse embryos, Fabp7 and P0 are not expressed at E10.5 in migrating neural crest cells, but can be detected as early as E11 in DRG and/or peripheral nerves (Kurtz et al., 1994; Hagedorn et al., 1999; Britsch et al., 2001; Jacob et al., 2014). At E11, P0 mRNA is expressed in Schwann cell precursors of distal nerves and ventral roots (Jacob et al., 2014), and at E12, expression extends to satellite cells in the DRG. Expression in Schwann cell precursors of dorsal roots occurs later (Hagedorn et al., 1999). P0 is an early marker of peripheral glia lineage in embryos of various other animal 
species including chick and rat, where expression has been detected already in migrating neural crest (Bhattacharyya et al., 1991; Lee et al., 1997). P0 is the most abundant structural protein of peripheral myelin, and protein levels are low before the establishment of 1:1 relationships between Schwann cells and peripheral axons, which precedes the onset of myelination (Martini et al., 1988; Lee et al., 1997). However, P0 protein is produced at higher levels in boundary cap cells at the dorsal root entry zone, with a peak of expression from E13 till E16 in mouse embryos (Golding and Cohen, 1997). P0 may be expressed at this developmental stage to maintain the coherence of boundary cap cell clusters by its homophilic adhesion properties (Filbin et al., 1990). Interestingly, P0 has also been shown to promote neurite outgrowth (Schneider-Schaulies et al., 1990; Filbin and Tennekoon, 1992). As for Fabp7, a role in regulating Schwann cell-axon interactions has been proposed (Miller et al., 2003) and it is certainly critical for neurogenesis in the CNS (recently reviewed in Matsumata et al., 2014), but its function in peripheral glia remains unclear.

Desert-Hedgehog (Dhh) is a signaling molecule that is also expressed in Schwann cell precursors and remains expressed at later stages of the Schwann cell lineage. This protein belongs to a group of secreted factors that are involved in cell-cell interactions (Bitgood and McMahon, 1995). Dhh expression is induced by Sox10 in Schwann cells (Küspert et al., 2012), where it holds key functions in the development of peripheral nerves (Parmantier et al., 1999; Sharghi-Namini et al., 2006). Indeed, Dhh released by Schwann cells signals through its receptor Patched expressed by perineurial fibroblasts, which in turn form and maintain the integrity of the nerve-blood barrier (Parmantier et al., 1999).

Glutamine synthetase can also be used as a marker of peripheral glia in adult DRG and peripheral nerves. Indeed, this enzyme is expressed in satellite glia and Schwann cells, while DRG neuronal cell bodies and peripheral axons express glutaminase (Miller et al., 2002). However, there is no evidence in the literature that glutamine synthetase is already expressed in satellite cells and Schwann cell precursors during embryonic development. Peripheral glia take up glutamate from the extracellular environment and quickly convert it to glutamine by their glutamine synthetase. Glutamine is then transported to neurons and subsequently converted to glutamate by their glutaminase. Neurons can then use glutamate for synaptic transmission or to enter their metabolic cycle. DRG and peripheral neurons activity and metabolism are therefore highly dependent on their interaction with peripheral glia.

As discussed above, many markers are common to different types of peripheral glia. However, specific markers for almost each type of peripheral glial cells have also been described and can thus be used to distinguish them when localization is not sufficient. Indeed, satellite cells express the Ets domain transcription factor Erm that is not expressed in Schwann cell precursors. However, Erm is also expressed in peripheral neurons and in migrating PNS-committed neural crest cells (Hagedorn et al., 2000). Erm does not seem to be required for survival or proliferation of neural crest cells, but is critical for neuron specification and proliferation of satellite glia (Paratore et al., 2002).

Boundary cap cells are characterized by their robust expression of the zinc finger transcription factor Krox20 starting from E10.5 in mouse embryos (Topilko et al., 1994). At E11.5, ventral and dorsal root Schwann cell precursors also express Krox20 (Topilko et al., 1994), but no expression in other types of peripheral glia is detected before E15.5 when Schwann cell precursors further differentiate into immature Schwann cells (Murphy et al., 1996). Although satellite cells can express Krox20 in culture and thereby convert to a Schwann cell fate, they do not express Krox20 in vivo (Murphy et al., 1996), maybe due to repressive signaling in the DRG. Krox20 is an essential transcription factor of Schwann cell myelination (Topilko et al., 1994) that induces expression of myelin genes including PO, PMP22, MAG, MBP, periaxin (Nagarajan et al., 2001; LeBlanc et al., 2006; Jang et al., 2006, 2009, 2010; Svaren and Meijer, 2008; Jones et al., 2011; Srinivasan et al., 2012) and represses the marker of promyelinating Schwann cells Oct6 (Jaegle et al., 1996) and markers of immature Schwann cells such as Sox2, Id2, c-jun, and $775^{\text {NTR }}$ (Parkinson et al., 2004; Le et al., 2005; Srinivasan et al., 2006, 2012; Mager et al., 2008; Hung et al., 2012). The function of Krox20 in boundary cap cells and nerve root Schwann cell precursors during embryonic development appears less clear. Krox20 has been shown to control the expression of $L 20$, another gene specifically expressed in boundary cap cells (Coulpier et al., 2009), however the function of L2O is currently unknown. Wifl, a gene encoding a secreted protein that antagonizes Wnt-dependent signaling (Hsieh et al., 1999), has also been reported to mark boundary cap cells (Coulpier et al., 2009), as well as genes encoding the natriuretic peptide receptor $N r p 3$, the Notch-dependent basic helix-loop-helix transcription factor $H e y 2$, and the embryonic and adult hemoglobins $H b b-y$ and $H b b-b 1,4$ genes that are also expressed in nerve root Schwann cell precursors (Coulpier et al., 2009). Ablation of Krox2O or Hey2 in mouse embryos does not lead to survival defects in boundary cap cells (Coulpier et al., 2009), and the functions of these genes in the biology of boundary cap cells have not yet been identified. Boundary cap cells have also been shown to express monoamine oxidase $\mathrm{B}$ (MAOB); however, MAOB is widely expressed in other neural crest derived cells including chondrocytes, sensory neurons, and most likely also olfactory ensheathing cells (Vitalis et al., 2003). 


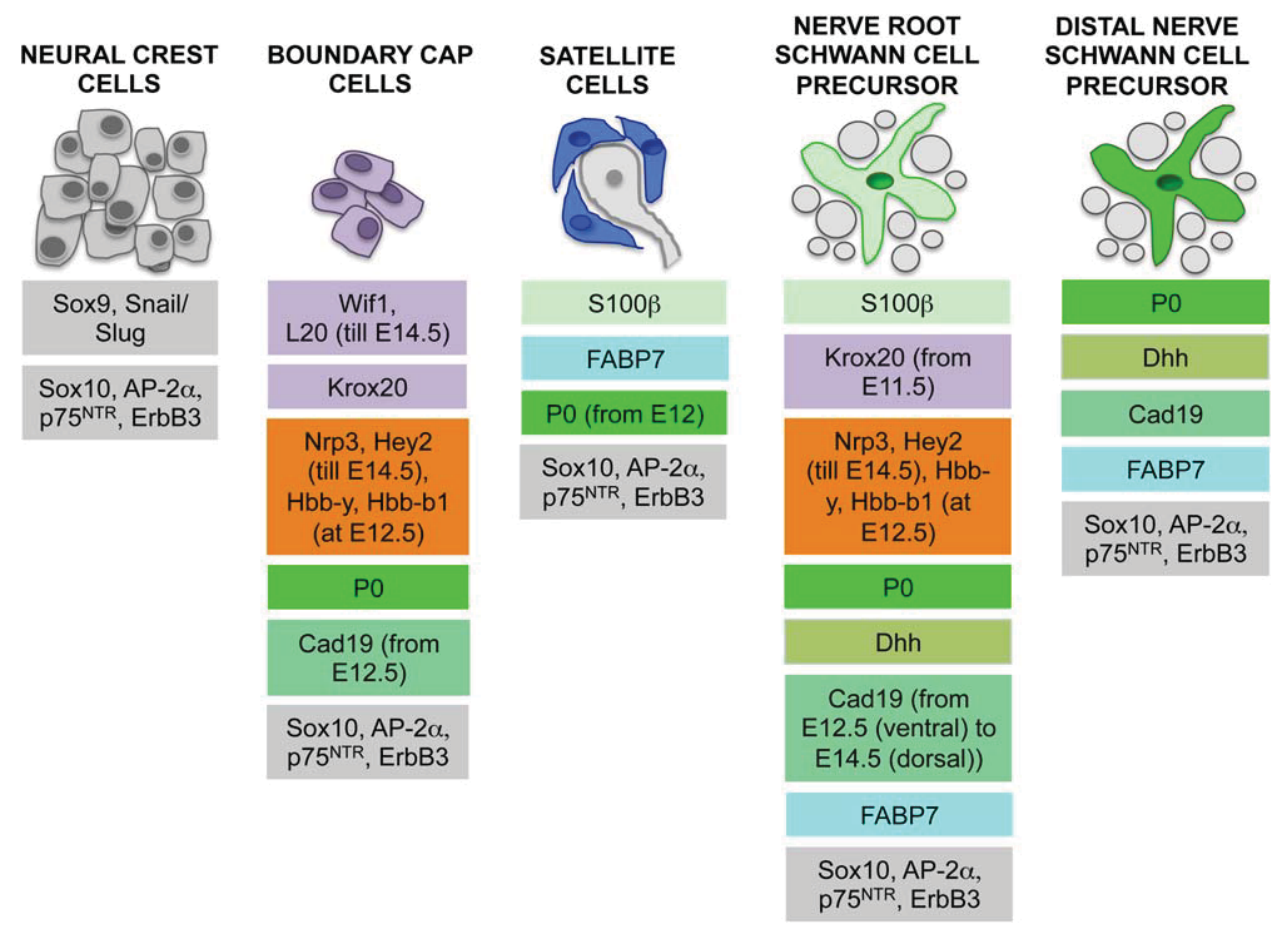

FIGURE 6: Specific markers of peripheral glia and their progenitors. Colors are used for easier identification of markers that are expressed in several lineages. When appropriate, the embryonic stage (E) corresponding to mouse development is given. Factors that are expressed in these lineages, but also strongly expressed in other cell types such as neurons or not expressed during embryonic development are not represented here, but they are discussed in the main text.

Because most Schwann cell precursors found in nerve roots derive from boundary cap cells, they do not only express Schwann cell precursor markers, but also genes that mark boundary cap cells. In addition, nerve root Schwann cell precursors express the $\mathrm{Ca}^{2+}$-binding protein S100 already at E12.5 in mouse embryos (Murphy et al., 1996), while Schwann cell precursors of distal peripheral nerves are S100-negative (Jessen et al., 1994). In distal peripheral nerves, the transition from Schwann cell precursors to immature Schwann cells is marked by the expression of S100. This suggests that Schwann cell precursors in nerve roots may progress faster into the immature Schwann cell stage. However, nerve root Schwann cell precursors also express cadherin-19, which is downregulated in immature Schwann cells (Takahashi and Osumi, 2005). Satellite glia and DRG neurons also express S100 (Cocchia and Michetti, 1981; Stefansson et al 1982; Lauriola et al., 1989), however histochemical analyses of $S 100$ protein subunits showed that $S 100 \beta$ subunit is more prominently expressed in peripheral glia, while $S 100 \alpha$ is expressed in both neurons and peripheral glia (Sugimura et al., 1989; Vega et al., 1991).

Interestingly, Seraf that encodes a secreted protein containing several EGF-like repeats, has been identified as a very early marker of Schwann cell precursors in chick embryos. Indeed, Seraf is expressed before P0 in Schwann cell precursors and its expression is downregulated when P0 starts being expressed (Wakamatsu et al., 2004b). However, the function of Seraf has not been further investigated and remains therefore unknown.

Other proteins including the myelin proteins PMP22 (Hagedorn et al., 1999) and PLP/DM20 (Griffiths et al., 1998), as well as the growth-associated protein GAP-43 have also been described as early peripheral glia markers, however they are also at least transiently expressed in neurons during embryonic development. PMP22 transcript is detected in DRG and peripheral nerves starting from E12 in mouse embryos, and is expressed in peripheral glia, but also DRG neurons (Hagedorn et al., 1999). While PLP is predominantly found in oligodendrocytes in the CNS, its short isoform DM20 is mostly expressed in other tissues. In mouse embryos, DM20 is expressed from E13 in Schwann cell precursors and is also found in satellite cells (Griffiths et al., 1998; Tuason et al., 2008) and olfactory ensheathing cells (Dickinson et al., 1997). GAP-43 has been originally described as a growth cone protein expressed in neurons (Jacobson et al., 1986). It is not expressed in neural crest cells, but in addition to neurons, it is also expressed in CNS glia (Sensenbrenner et al., 1997) and in Schwann cell precursors and at later developmental stages in non-myelinating Schwann cells (Curtis et al., 1992; Jessen et al., 1994), where it is involved in the formation of cellular processes.

The different neural crest and peripheral glia markers are summarized in Fig. 6, however the factors described in 
this chapter that display strong expression in neurons or that have not been detected during embryonic development are not represented.

Olfactory ensheathing cells that are found in both PNS and CNS and originate from the neural crest show similar pattern of gene expression to Schwann cells, but some differences exist. Indeed, Ulrich et al. (2014) recently published a gene expression profiling analysis comparing Schwann cells and olfactory ensheathing cells. This study shows that olfactory ensheathing cells express lower levels of the Schwann cell-lineage marker genes including ErbB3, GFAP (not expressed in Schwann cell precursors, but later in the Schwann cell lineage), $p 75^{N T R}$, Dhh, AP2- $\alpha, P 0, L 1$, but higher levels of an $S 100 \alpha$ subunit and of GAP-43. Other differences among genes that are not Schwann cell-specific markers include higher levels of Hoxc4 and Hoxd8 and lower levels of Cntnap2 and Efemp1 in Schwann cells compared with olfactory ensheathing cells (Ulrich et al., 2014).

\section{Conclusion}

Despite the many years that developmental biologists have dedicated to understand the origin of neural crest cells and derived lineages, their migration routes, specification and survival mechanisms, major discoveries on this topic are still emerging. If we consider the complexity of transcriptional events and regulations that control these mechanisms, this is not at all surprising. The fact that such an intricate network of transcription factors is successfully orchestrated to deliver the many neural crest derived cell types of the body at their respective locations still seems like an enormous challenge. As discussed in this review, the action of transcription factors is controlled by a combination of extracellular cues and signaling pathways. Recent studies also highlight the critical functions of chromatin remodeling factors in the control of transcription factor expression and activity. Our current knowledge of transcriptional regulations occurring at the chromatin level in the nervous system is still very scarce (functions of HDACs and histone methylation enzymes reviewed in Jacob et al., 2011b and Pattaroni and Jacob, 2013). It is therefore reasonable to envision that future work on this topic will deliver breakthrough findings in developmental biology. Besides developmental mechanisms, control of regeneration processes will certainly also benefit from deeper knowledge of chromatin-remodeling events that control cell differentiation, de-differentiation and fate switch. In this respect, the plasticity of Schwann cells, olfactory ensheathing cells, and mesenchymal stem cells that are found in adult tissues (not discussed in this review), together with in-depth understanding of the mechanisms that control their cell cycle, appear as very promising strategies to explore for future applications in regenerative medicine.

\section{Acknowledgment}

Grant sponsor: Swiss National Science Foundation (SNSF Professorship); Grant number: PP00P3_139163/1

\section{References}

Adameyko I, Lallemend F, Aquino JB, Pereira JA, Topilko P, Müller T, Fritz N Beljajeva A, Mochii M, Liste I, Usoskin D, Suter U, Birchmeier C, Ernfors P. 2009. Schwann cell precursors from nerve innervation are a cellular origin of melanocytes in skin. Cell 139:366-379.

Antonellis A, Huynh JL, Lee-Lin SQ, Vinton RM, Renaud G, Loftus SK, Elliot G, Wolfsberg TG, Green ED, McCallion AS, Pavan WJ. 2008. Identification of neural crest and glial enhancers at the mouse Sox10 locus through transgenesis in zebrafish. PLoS Genet 4:e1000174

Aoki Y, Saint-Germain N, Gyda M, Magner-Fink E, Lee YH, Credidio C, SaintJeannet JP. 2003. Sox10 regulates the development of neural crest-derived melanocytes in xenopus. Dev Biol 259:19-33.

Auerbach R. 1954. Analysis of the developmental effects of a lethal mutation in the house mouse. J Exp Zool 127:305-329.

Aybar MJ, Nieto MA, Mayor R. 2003. Snail precedes slug in the genetic cascade required for the specification and migration of the xenopus neural crest. Development 130:483-494.

Bagheri-Fam S, Barrionuevo F, Dohrmann U, Gunther T, Schüle R, Kemler R, Mallo M, Kanzler B, Scherer G. 2006. Long-range upstream and downstream enhancers control distinct subsets of the complex spatiotemporal Sox 9 expression pattern. Dev Biol 291:382-397.

Bajpai R, Chen DA, Rada-Iglesias A, Zhang J, Xiong Y, Helms J, Chang CP Zhao Y, Swigut T, Wysocka J. 2010. CHD7 cooperates with PBAF to control multipotent neural crest formation. Nature 463:958-962.

Barraud P, Seferiadis AA, Tyson LD, Zwart MF, Szabo-Rogers HL, Ruhrberg C, Liu KJ, Baker CVH. 2010. Neural crest origin of olfactory ensheathing glia. Proc Natl Acad Sci USA 107:21040-21045

Betancur P, Bronner-Fraser M, Sauka-Spengler T. 2010. Assembling neural crest regulatory circuits into agene regulatory network. Annu Rev Cell Dev Biol 26:581-603.

Bhattacharyya A, Frank E, Ratner N, Brackenbury R. 1991. PO is an early marker of the schwann cell lineage in chickens. Neuron 7:831-844.

Bitgood MJ, McMahon AP. 1995. Hedgehog and bmp genes are coexpressed at many diverse sites of cell-cell interaction in the mouse embryo. Dev Biol 172:126-138.

Bondurand N, Girard M, Pingault V, Lemort N, Dubourg O, Goossens M. 2001. Human connexin 32, a gap junction protein altered in the X-linked form of Charcot-Marie-tooth disease, is directly regulated by the transcription factor SOX10. Hum Mol Genet 10:2783-2795.

Bremer M, Fröb F, Kichko T, Reeh P, Tamm ER, Suter U, Wegner M. 2011. Sox10 is required for Schwann-cell homeostasis and myelin maintenance in the adult peripheral nerve. Glia 59:1022-1032.

Britsch S, Goerich DE, Riethmacher D, Peirano RI, Rossner M, Nave KA, Birchmeier C, Wegner M. 2001. The transcription factor Sox10 is a key regulator of peripheral glial development. Genes Dev 15:66-78.

Bron R, Vermeren M, Kokot N, Andrews W, Little GE, Mitchell KJ, Cohen J. 2007. Boundary cap cells constrain spinal motor neuron somal migration at motor exit points by a semaphorin-plexin mechanism. Neural Dev 2:21.

Cao R, Zhang Y. 2004. Suz12 is required for both the histone methyltransferase activity and the silencing function of the EED-EZH2 complex. Mol Cell 15:57-67.

Carney TJ, Dutton KA, Greenhill E, Delfino-Machín M, Dufourcq P, Blader P, Kelsh RN. 2006. A direct role for Sox10 in specification of neural crestderived sensory neurons. Development 133:4619-4630.

Cheung M, Chaboissier MC, Mynett A, Hirst E, Schedl A, Briscoe J. 2005 The transcriptional control of trunk neural crest induction, survival, and delamination. Dev Cell 8:179-192. 
Cocchia D, Michetti F. 1981. S-100 antigen in satellite cells of the adrenal medulla and the superior cervical ganglion of the rat. An immunochemical and immunocytochemical study. Cell Tissue Res 215:103-112.

Coulpier F, Lecrom S, Maro GS, Manent J, Giovannini M, Maciorowski Z, Fischer A, Gessler M, Charnay P, Topilko P. 2009. Novel features of boundary cap cells revealed by the analysis of newly identified molecular markers. Glia 57:1450-1457.

Curtis R, Stewart HJS, Hall SM, Wilkin GP, Mirsky R, Jessen KR. 1992. is expressed by non myelin-forming schwann cells of the peripheral nervous system. J Cell Biol 116:1455-1464. GAP43

D'Antonio M, Michalovich D, Paterson M, Droggiti A, Woodhoo A, Mirsky R, Jessen KR. 2006a. Gene profiling and bioinformatic analysis of schwann cell embryonic development and myelination. Glia 53:501-515.

Del Barrio MG, Nieto MA. 2002. Overexpression of snail family members highlights their ability to promote chick neural crest formation. Development 129:1583-1593.

Dickinson PJ, Griffiths IR, Barrie JM, Kyriakides E, Pollock GF, Barnett SC. 1997 Expression of the $\mathrm{dm}-20$ isoform of the plp gene in olfactory nerve ensheathing cells: evidence from developmental studies. J Neurocytol 26:181-189.

Doddrell RD, Dun XP, Moate RM, Jessen KR, Mirsky R, Parkinson DB. 2012. Regulation of schwann cell differentiation and proliferation by the Pax-3 transcription factor. Glia 60:1269-1278.

Donoghue PCJ, Graham A, Kelsh RN. 2008. The origin and evolution of the neural crest. Bioessays 30:530-541.

Dyachuk V, Furlan A, Shahidi MK, Giovenco M, Kaukua N, Konstantinidou C, Pachnis V, Memic F, Marklund U, Müller T, Birchmeier C, Fried K, Ernfors P, Adameyko I. 2014. Neurodevelopment. Parasympathetic neurons originate from nerve-associated peripheral glial progenitors. Science 345:82-87.

Eroglu B, Wang G, Tu N, Sun X, Mivechi NF. 2006. Critical role of Brg1 member of the SWI/SNF chromatin remodeling complex during neurogenesis and neural crest induction in zebrafish. Dev Dyn 235:2722-2735.

Espinosa-Medina I, Outin E, Picard CA, Chettouh Z, Dymecki S, Consalez GG, Coppola E, Brunet JF. 2014. Neurodevelopment. Parasympathetic ganglia derive from schwann cell precursors. Science 345:87-90.

Faissner A, Kruse J, Nieke J, Schachner M. 1984. Expression of neural cell adhesion molecule L1 during development, in neurological mutants and in the peripheral nervous system. Brain Res 317:69-82.

Filbin MT, Walsh FS, Trapp BD, Pizzey JA, Tennekoon GI. 1990. Role of myelin PO protein as a homophilic adhesion molecule. Nature 344:871-872

Filbin MT, Tennekoon GI. 1992. Myelin P0-protein, more than just a structural protein? Bioessays 14:541-547

Finzsch M, Schreiner S, Kichko T, Reeh P, Tamm ER, Bösl MR, Meijer D, Wegner M. 2010. Sox10 is required for schwann cell identity and progression beyond the immature schwann cell stage. J Cell Biol 189:701-712.

Fischer G, Künemund V, Schachner M. 1986. Neurite outgrowth patterns in cerebellar microexplant cultures are affected by antibodies to the cell surface glycoprotein L1. J Neurosci 6:605-612.

Franz T. 1990. Defective ensheathment of motoric nerves in the splotch mutant mouse. Acta Anat 138:246-253

Fritzsch B, Northcutt RG. 1993. Cranial and spinal nerve organization in amphioxus and lampreys: evidence for an ancestral craniate pattern. Acta Anatomica 148:96-109.

Fröb $F$, Bremer $M$, Finzsch $M$, Kichko $T$, Reeh $P$, Tamm ER, Charnay $P$, Wegner M. 2012. Establishment of myelinating schwann cells and barrier integrity between central and peripheral nervous systems depend on Sox10 Glia 60:806-819.

Fujita K, Ogawa R, Kawawaki S, Ito K. 2014. Roles of chromatin remodelers in maintenance mechanisms of multipotency of mouse trunk neural crest cells in the formation of neural crest-derived stem cells. Mech Dev 133:126-145.

Garratt AN, Britsch S, Birchmeier C. 2000. Neuregulin, a factor with many functions in the life of a schwann cell. Bioessays 22:987-996.
Ghislain J, Charnay P. 2006. Control of myelination in schwann cells: A Krox20 cis-regulatory element integrates Oct6, Brn2 and Sox10 activities. EMBO Rep 7:52-58.

Golding JP, Cohen J. 1997. Border controls at the mammalian spinal cord: Late-surviving neural crest boundary cap cells at dorsal root entry sites may regulate sensory afferent ingrowth and entry zone morphogenesis. Mol Cell Neurosci 9:381-396.

Gouti M, Briscoe J, Gavalas A. 2011. Anterior hox genes interact with components of the neural crest specification network to induce neural crest fates. Stem Cells 29:858-870.

Griffiths I, Klugmann M, Anderson T, Thomson C, Vouyiouklis D, Nave K-A 1998. Current concepts of plp and its role in the nervous system. Microsc Res Tech 41:344-358.

Hagedorn L, Suter U, Sommer L. 1999. PO and PMP22 mark a multipotent neural crest-derived cell type that displays community effects in response to TGF-beta family factors. Development 126:3781-3794.

Hari L, Brault V, Kléber M, Lee HY, Ille F, Leimeroth R, Paratore C, Suter U, Kemler R, Sommer L. 2002. Lineage-specific requirements of beta-catenin in neural crest development. J Cell Biol 159:867-880.

Herbarth B, Pingault V, Bondurand N, Kuhlbrodt K, Hermans-Borgmeyer I, Puliti A, Lemort N, Goossens M, Wegner M. 1998. Mutation of the Sryrelated Sox10 gene in dominant megacolon, a mouse model for human hirschsprung disease. Proc Natl Acad Sci USA 95:5161-5165.

Hjerling-Leffler J, Marmigère $F$, Heglind $M$, Cederberg $A$, Koltzenburg $M$, Enerbäck S, Ernfors P. 2005. The boundary cap: A source of neural crest stem cells that generate multiple sensory neuron subtypes. Development 132:2623-2632.

Hong CS, Saint-Jeannet JP. 2007. The activity of Pax3 and Zic1 regulates three distinct cell fates at the neural plate border. Mol Biol Cell 18:21922202.

Honoré SM, Aybar MJ, Mayor R. 2003. Sox10 is required for the early development of the prospective neural crest in xenopus embryos. Dev Biol 260: 79-96

Hsieh JC, Kodjabachian L, Rebbert ML, Rattner A, Smallwood PM, Samos $\mathrm{CH}$, Nusse R, Dawid IB, Nathans J. 1999. A new secreted protein that binds to wnt proteins and inhibits their activities. Nature 398:431-436.

Hu N, Strobl-Mazzulla P, Sauka-Spengler T, Bronner ME. 2012. DNA methyltransferase $3 \mathrm{~A}$ as a molecular switch mediating the neural tube-to-neura crest fate transition. Genes Dev 26:2380-2385

Hung H, Kohnken R, Svaren J. 2012. The nucleosome remodeling and deacetylase chromatin remodeling (NuRD) complex is required for peripheral nerve myelination. J Neurosci 32:1517-1527.

Ignatius MS, Moose HE, El-Hodiri HM, Henion PD. 2008. colgate/hdac1 repression of foxd3 expression is required to permit mitfa-dependent melanogenesis. Dev Biol 313:568-583.

Jacob C, Grabner H, Atanasoski S, Suter U. 2008. Expression and localization of ski determine cell type-specific effects of TGFbeta on the cell cycle. J Cell Biol 182:519-530.

Jacob C, Lebrun-Julien F, Suter U. 2011b. How histone deacetylases control myelination. Mol Neurobiol 44:303-312.

Jacob C, Lötscher P, Engler S, Baggiolini A, Varum Tavares S, Brügger V John N, Büchmann-Møller S, Snider PL, Conway SJ, Yamaguchi T, Matthias P, Sommer L, Mantei N, Suter U. 2014. HDAC1 and HDAC2 control the specification of neural crest cells into peripheral glia. J Neurosci 34:6112-6122.

Jacobson RD, Virág I, Skene JH. 1986. A protein associated with axon growth, GAP-43, is widely distributed and developmentally regulated in rat CNS. J Neurosci 6:1843-1855.

Jaegle M, Mandemakers W, Broos L, Zwart R, Karis A, Visser P, Grosveld F, Meijer D. 1996. The POU factor Oct-6 and schwann cell differentiation. Science 273:507-510.

Jagalur NB, Ghazvini M, Mandemakers W, Driegen S, Maas A, Jones EA Jaegle M, Grosveld F, Svaren J, Meijer D. 2011. Functional dissection of the 
Oct6 schwann cell enhancer reveals an essential role for dimeric Sox10 binding. J Neurosci 31:8585-8594.

Jang SW, LeBlanc SE, Roopra A, Wrabetz L, Svaren J. 2006. In vivo detection of Egr2 binding to target genes during peripheral nerve myelination. J Neurochem 98:1678-1687.

Jang SW, Svaren J. 2009. Induction of myelin protein zero by early growth response 2 through upstream and intragenic elements. J Biol Chem 284: 20111-20120.

Jessen KR, Brennan A, Morgan L, Mirsky R, Kent A, Hashimoto Y, Gavrilovic J. 1994. The schwann cell precursor and its fate: A study of cell death and differentiation during gliogenesis in rat embryonic nerves. Neuron 12:509527.

Jessen KR, Mirsky R. 2005. The origin and development of glial cells in peripheral nerves. Nat Rev Neurosci 6:671-682.

Jones CM, Lyons KM, Hogan BL. 1991. Involvement of bone morphogenetic protein-4 (BMP-4) and Vgr-1 in morphogenesis and neurogenesis in the mouse. Development 111:531-542.

Jones NC, Trainor PA. 2005. Role of morphogens in neural crest cell determination. J Neurobiol 64:388-404.

Joseph NM, Mukouyama YS, Mosher JT, Jaegle M, Crone SA, Dormand EL, Lee KF, Meijer D, Anderson DJ, Morrison SJ. 2004. Neural crest stem cells undergo multilineage differentiation in developing peripheral nerves to generate endoneurial fibroblasts in addition to schwann cells. Development 131 $5599-5612$

Katoh H, Shibata S, Fukuda K, Sato M, Satoh E, Nagoshi N, Minematsu T, Matsuzaki Y, Akazawa C, Toyama Y, Nakamura M, Okano H. 2011. The dual origin of the peripheral olfactory system: Placode and neural crest. Mol Brain 4:34-

Kaukua N, Shahidi MK, Konstantinidou C, Dyachuk V, Kaucka M, Furlan A, An Z, Wang L, Hultman I, Ahrlund-Richter L, Blom H, Brismar H, Lopes NA Pachnis V, Suter U, Clevers H, Thesleff I, Sharpe P, Ernfors P, Fried K, Adameyko I. 2014. Glial origin of mesenchymal stem cells in a tooth model system. Nature 513:551-554.

Kim H, Kang K, Ekram MB, Roh T-Y, Kim J. 2011. Aebp2 as an epigenetic regulator for neural crest cells. PLoS One 6:e25174-

Kioussi C, Gross MK, Gruss P. 1995. Pax3: A paired domain gene as a regulator in PNS myelination. Neuron 15:553-562.

Kuhlbrodt K, Herbarth B, Sock E, Hermans-Borgmeyer I, Wegner M. 1998. Sox10, a novel transcriptional modulator in glial cells. J Neurosci 18:237-250.

Kurtz A, Zimmer A, Schnütgen F, Brüning G, Spener F, Müller T. 1994. The expression pattern of a novel gene encoding brain-fatty acid binding protein correlates with neuronal and glial cell development. Development 120:26372649.

Küspert M, Weider M, Müller J, Hermans-Borgmeyer I, Meijer D, Wegner M. 2012. Desert hedgehog links transcription factor Sox10 to perineurial development. J Neurosci 32:5472-5480.

Lauriola L, Michetti F, Coli A, Bigotti G, Cocchia D. 1989. Satellite cells in developing spinal ganglia. An immunohistochemical study. Int J Dev Neurosci 7:275-279.

Le N, Nagarajan R, Wang JY, Araki T, Schmidt RE, Milbrandt J. 2005. Analysis of congenital hypomyelinating Egr2Lo/lo nerves identifies Sox2 as an inhibitor of schwann cell differentiation and myelination. Proc Natl Acad Sci USA 102:2596-2601.

LeBlanc SE, Jang SW, Ward RM, Wrabetz L, Svaren J. 2006. Direct regulation of myelin protein zero expression by the Egr2 transactivator. J Biol Chem 281:5453-5460.

Lee M, Brennan A, Blanchard A, Zoidl G, Dong Z, Tabernero A, Zoidl C, Dent MA, Jessen KR, Mirsky R. 1997. Mol Cell Neurosci 8:336-350.

Lin J, Luo J, Redies C. 2010. Cadherin-19 expression is restricted to myelinforming cells in the chicken embryo. Neuroscience 165:168-178.

Linker C, Bronner-Fraser M, Mayor R. 2000. Relationship between gene expression domains of xsnail, xslug, and xtwist and cell movement in the prospective neural crest of xenopus. Dev Biol 224:215-225.
Locascio A, Manzanares M, Blanco MJ, Nieto MA. 2002. Modularity and reshuffling of snail and slug expression during vertebrate evolution. Proc Natl Acad Sci USA 99:16841-16846.

Luo T, Lee YH, Saint-Jeannet JP, Sargent TD. 2003. Induction of neural crest in xenopus by transcription factor AP2 $\alpha$. Proc Natl Acad Sci USA 100 532-537.

Ma Q, Fode C, Guillemot F, Anderson DJ. 1999. Neurogenin1 and neurogenin2 control two distinct waves of neurogenesis in developing dorsal root ganglia. Genes Dev 13:1717-1728.

Mager GM, Ward RM, Srinivasan R, Jang SW, Wrabetz L, Svaren J. 2008 Active gene repression by the Egr2.NAB complex during peripheral nerve myelination. J Biol Chem 283:18187-18197.

Maro GS, Vermeren M, Voiculescu O, Melton L, Cohen J, Charnay P, Topilko P. 2004. Neural crest boundary cap cells constitute a source of neuronal and glial cells of the PNS. Nat Neurosci 7:930-938.

Martini R, Bollensen E, Schachner M. 1988. Immunocytological localization of the major peripheral nervous system glycoprotein PO and the L2/HNK-1 and L3 carbohydrate structures in developing and adult mouse sciatic nerve. Dev Biol 129:330-338.

Matsumata M, Inada H, Osumi N. 2014. Fatty acid binding proteins and the nervous system: their impact on mental conditions. Neurosci Res doi: 10.1016/j.neures.2014.08.012

Mayor R, Guerrero N, Martinez C. 1997. Role of FGF and noggin in neural crest induction. Dev Biol 189:1-12.

McGraw HF, Nechiporuk A, Raible DW. 2008. Zebrafish dorsal root ganglia neural precursor cells adopt a glial fate in the absence of neurogenin 1 . J Neurosci 28:12558-12569.

Meyer D, Birchmeier C. 1995. Multiple essential functions of neuregulin in development. Nature 378:386-390

Michailov GV, Sereda MW, Brinkmann BG, Fischer TM, Haug B, Birchmeier C, Role L, Lai C, Schwab MH, Nave K-A. 2004. Axonal Neuregulin-1 regulates myelin sheath thickness. Science 304:700-703.

Milet C, Maczkowiak F, Roche DD, Monsoro-Burq AH. 2013. Pax3 and Zic1 drive induction and differentiation of multipotent, migratory, and functional neural crest in xenopus embryos. Proc Natl Acad Sci USA 110:5528-5533.

Miller KE, Richards BA, Kriebel RM. 2002. Glutamine-, glutamine synthetaseglutamate dehydrogenase- and pyruvate carboxylase-immunoreactivities in the rat dorsal root ganglion and peripheral nerve. Brain Res 945:202-211.

Miller SJ, Li H, Rizvi TA, Huang Y, Johansson G, Bowersock J, Sidani A Vitullo J, Vogel K, Parysek LM, DeClue JE, Ratner N. 2003. Brain lipid binding protein in axon-schwann cell interactions and peripheral nerve tumorigenesis. Mol Cell Biol 23:2213-2224.

Mirsky R, Jessen KR, Schachner M, Goridis C. 1986. Distribution of the adhesion molecules N-CAM and L1 on peripheral neurons and glia in adult rats. J Neurocytol 15:799-815.

Morgan MJ, Woltering JM, Inder Rieden PMJ, Durston AJ, Thiery JP. 2004 YY1 regulates the neural crest-associated slug gene in xenopus laevis. J Biol Chem 279:46826-46834.

Morrison SJ. 2001. Neuronal potential and lineage determination by neural stem cells. Curr Opin Cell Biol 13:666-672.

Morrison SJ, White PM, Zock C, Anderson DJ. 1999. Prospective identification, isolation by flow cytometry, and in vivo self-renewal of multipotent mammalian neural crest stem cells. Cell 96:737-749.

Murphy P, Topilko P, Schneider-Maunoury S, Seitanidou T, Baron-Van Evercooren A, Charnay P. 1996. The regulation of Krox-20 expression reveals important steps in the control of peripheral glial cell development. Development 122:2847-2857

Nagarajan R, Svaren J, Le N, Araki T, Watson M, Milbrandt J. 2001. EGR2 mutations in inherited neuropathies dominant-negatively inhibit myelin gene expression. Neuron 30:355-368 
Nagatomo K, Hashimoto C. 2007. Xenopus hairy2 functions in neural crest formation by maintaining cells in a mitotic and undifferentiated state. Dev Dyn 236:1475-1483.

Nichane M, de Crozé N, Ren X, Souopgui J, Monsoro-Burq AH, Bellefroid EJ. 2008. Hairy2-Id3 interactions play an essential role in xenopus neural crest progenitor specification. Dev Biol 322:355-367.

Niederländer C, Lumsden A. 1996. Late emigrating neural crest cells migrate specifically to the exit points of cranial branchiomotor nerves. Development $122: 2367-2374$

Nitzan E, Krispin S, Pfaltzgraff ER, Klar A, Labosky PA, Kalcheim C. 2013a. A dynamic code of dorsal neural tube genes regulates the segregation between neurogenic and melanogenic neural crest cells. Development 140: 2269-2279

Nitzan E, Pfaltzgraff ER, Labosky PA, Kalcheim C. 2013b. Neural crest and schwann cell progenitor-derived melanocytes are two spatially segregated populations similarly regulated by Foxd3. Proc Natl Acad Sci USA 110 12709-12714.

O'Donnell M, Hong CS, Huang X, Delnicki RJ, Saint-Jeannet JP. 2006. Functional analysis of Sox8 during neural crest development in xenopus. Development 133:3817-3826

Olaopa M, Zhou HM, Snider P, Wang J, Schwartz RJ, Moon AM, Conway SJ. 2011. Pax3 is essential for normal cardiac neural crest morphogenesis but is not required during migration nor outflow tract septation. Dev Biol 356:308-322.

Ota M, Ito K. 2006. BMP and FGF-2 regulate neurogenin-2 expression and the differentiation of sensory neurons and glia. Dev Dyn 235:646-655.

Paratore C, Goerich DE, Suter U, Wegner M, Sommer L. 2001. Survival and glial fate acquisition of neural crest cells are regulated by an interplay between the transcription factor Sox10 and extrinsic combinatorial signaling. Development 128:3949-3961

Parkinson DB, Bhaskaran A, Droggiti A, Dickinson S, D’Antonio M, Mirsky R Jessen KR. 2004. Krox-20 inhibits Jun-NH2-terminal kinase/c-jun to control schwann cell proliferation and death. J Cell Biol 164:385-394.

Parmantier E, Lynn B, Lawson D, Turmaine M, Namini SS, Chakrabarti L, McMahon AP, Jessen KR, Mirsky R. 1999. Schwann cell-derived desert hedgehog controls the development of peripheral nerve sheaths. Neuron 23 : 713-724

Pattaroni C, Jacob C. 2013. Histone methylation in the nervous system: Functions and dysfunctions. Mol Neurobiol 47:740-756.

Patthey C, Schlosser G, Shimeld SM. 2014. The evolutionary history of vertebrate cranial placodes - I: cell type evolution. Dev Biol 389:82-97.

Peirano RI, Goerich DE, Riethmacher D, Wegner M. 2000. Protein zero gene expression is regulated by the glial transcription factor Sox10. Mol Cell Bio 20:3198-3209

Petratos S, Butzkueven H, Shipham K, Cooper H, Bucci T, Reid K, Lopes E, Emery B, Cheema SS, Kilpatrick TJ. 2003. Schwann cell apoptosis in the postnatal axotomized sciatic nerve is mediated via NGF through the low-affinity neurotrophin receptor. J Neuropathol Exp Neurol 62:398-411.

Powell DR, Hernandez-Lagunas L, LaMonica K, Artinger B K. 2013. Prdm1a directly activates foxd3 and tfap2a during zebrafish neural crest specification. Development 140:3445-3455.

Prasad MK, Reed X, Gorkin DU, Cronin JC, McAdow AR, Chain K, Hodonsky CJ, Jones EA, Svaren J, Antonellis A, Johnson SL, Loftus SK, Pavan WJ, McCallion AS. 2011. SOX10 directly modulates ERBB3 transcription via an intronic neural crest enhancer. BMC Dev Biol 11:40

Rada-Iglesias A, Bajpai R, Prescott S, Brugmann S, Swigut T, Wysocka J. 2012. Epigenomic annotation of enhancers predicts transcriptional regulators of human neural crest. Cell Stem Cell 11:633-648.

Reiprich S, Kriesch J, Schreiner S, Wegner M. 2010. Activation of Krox20 gene expression by Sox10 in myelinating schwann cells. J Neurochem 112:744-754.

Riethmacher D, Sonnenberg-Riethmacher E, Brinkmann V, Yamaai T, Lewin GR, Birchmeier C. 1997. Severe neuropathies in mice with targeted mutations in the ErbB3 receptor. Nature 389:725-730.
Saint-Germain N, Lee YH, Zhang Y, Sargent TD, Saint-Jeannet JP. 2004 Specification of the otic placode depends on Sox9 function in xenopus. Development 131:1755-1763.

Sato T, Sasai N, Sasai Y. 2005. Neural crest determination by co-activation of Pax3 and Zic1 genes in xenopus ectoderm. Development 132:2355-2363.

Schmidt M, Huber L, Majdazari A, Schütz G, Williams T, Rohrer H. 2011. The transcription factors $A P-2 \beta$ and AP- $2 \alpha$ are required for survival of sympathetic progenitors and differentiated sympathetic neurons. Dev Biol 355:89-100.

Schneider-Schaulies J, von Brunn A, Schachner M. 1990. Recombinant peripheral myelin protein PO confers both adhesion and neurite outgrowthpromoting properties. J Neurosci Res 27:286-297.

Schneider C, Wicht H, Enderich J, Wegner M, Rohrer H. 1999. Bone morphogenetic proteins are required in vivo for the generation of sympathetic neurons. Neuron 24:861-870

Schreiner S, Cossais F, Fischer K, Scholz S, Bösl MR, Holtmann B, Sendtner M, Wegner M. 2007. Hypomorphic Sox10 alleles reveal novel protein functions and unravel developmental differences in glial lineages. Development 134:3271-3281

Sensenbrenner M, Lucas M, Deloulme JC. 1997. Expression of two neuronal markers, growth-associated protein 43 and neuron-specific enolase, in rat glial cells. J Mol Med 75:653-663. (Berl)

Shah NM, Groves AK, Anderson DJ. 1996. Alternative neural crest cell fates are instructively promoted by TGFbeta superfamily members. Cell 85:331-343.

Sharghi-Namini S, Turmaine M, Meier C, Sahni V, Umehara F, Jessen KR, Mirsky R. 2006. The structural and functional integrity of peripheral nerves depends on the glial-derived signal desert hedgehog. J Neurosci 26:63646376.

Shimotake T, Iwai N, Yanagihara J, Deguchi E, Fushiki S. 1995. Impaired proliferative activity of mesenchymal cells affects the migratory pathway for neural crest cells in the developing gut of mutant murine embryos. J Pediatr Surg 30:445-447.

Soilu-Hanninen M, Ekert P, Bucci T, Syroid D, Bartlett PF, Kilpatrick TJ. 1999. Nerve growth factor signaling through p75 induces apoptosis in schwann cells via a Bcl-2-independent pathway. J Neurosci 19:4828-4838.

Sommer L, Ma Q, Anderson DJ. 1996. Neurogenins, a novel family of atonalrelated bHLH transcription factors, are putative mammalian neuronal determination genes that reveal progenitor cell heterogeneity in the developing CNS and PNS. Mol Cell Neurosci 8:221-241.

Soo K, O'Rourke MP, Khoo PL, Steiner KA, Wong N, Behringer RR, Tam PP. 2002. Twist function is required for the morphogenesis of the cephalic neural tube and the differentiation of the cranial neural crest cells in the mouse embryo. Dev Biol 247:251-270.

Southard-Smith EM, Kos L, Pavan WJ. 1998. Sox10 mutation disrupts neural crest development in dom hirschsprung mouse model. Nat Genet 18:60-64.

Spokony RF, Aoki Y, Saint-Germain N, Magner-Fink E, Saint-Jeannet JP. 2002. The transcription factor Sox 9 is required for cranial neural crest development in xenopus. Development 129:421-432.

Srinivasan R, Mager GM, Ward RM, Mayer J, Svaren J. 2006. NAB2 represses transcription by interacting with the CHD4 subunit of the nucleosome remodeling and deacetylase (NuRD) complex. J Biol Chem 281:15129-15137.

Srinivasan R, Sun G, Keles S, Jones EA, Jang SW, Krueger C, Moran JJ, Svaren J. 2012. Genome-wide analysis of EGR2/SOX10 binding in myelinating peripheral nerve. Nucleic Acids Res 40:6449-6460.

Stefansson K, Wollmann RL, Moore BW. 1982. Distribution of S-100 protein outside the central nervous system. Brain Res 234:309-317.

Stewart HJ, Rougon G, Dong Z, Dean C, Jessen KR, Mirsky R. 1995. TGF-betas upregulate NCAM and L1 expression in cultured schwann cells, suppress cyclic AMP-induced expression of $\mathrm{O} 4$ and galactocerebroside, and are widely expressed in cells of the schwann cell lineage in vivo. Glia 15:419-436.

Stewart RA, Arduini BL, Berghmans S, George RE, Kanki JP, Henion PD, Look AT. 2006. Zebrafish foxd3 is selectively required for neural crest specification, migration and survival. Dev Biol 292:174-188. 
Strobl-Mazzulla PH, Sauka-Spengler T, Bronner-Fraser M. 2010. Histone demethylase JmjD2A regulates neural crest specification. Dev Cell 19:460 468 .

Sugimura K, Haimoto H, Nagura H, Kato K, Takahashi A. 1989. Immunohistochemical differential distribution of S-100 alpha and S-100 beta in the peripheral nervous system of the rat. Muscle Nerve 12:929-935.

Svaren J, Meijer D. 2008. The molecular machinery of myelin gene transcription in schwann cells. Glia 56:1541-1551.

Syroid DE, Maycox PJ, Soilu-Hanninen M, Petratos S, Bucci T, Burrola P Murray S, Cheema S, Lee KF, Lemke G, Kilpatrick TJ. 2000. Induction of postnatal schwann cell death by the low-affinity neurotrophin receptor in vitro and after axotomy. J Neurosci 20:5741-5747.

Takahashi M, Osumi N. 2005. Identification of a novel type II classical cadherin: rat cadherin19 is expressed in the cranial ganglia and schwann cell precursors during development. Dev Dyn 232:200-208.

Taveggia C, Zanazzi G, Petrylak A, Yano H, Rosenbluth J, Einheber S, Xu X Esper RM, Loeb JA, Shrager P, Chao MV, Falls DL, Role L, Salzer JL. 2005. Neuregulin-1 type III determines the ensheathment fate of axons. Neuron 47: 681-694.

Teng L, Mundell NA, Frist AY, Wang Q, Labosky PA. 2008. Requirement for Foxd3 in maintenance of neural crest progenitors. Development 135:1615-1624.

Theveneau E, Mayor R. 2012. Neural crest delamination and migration: From epithelium-to-mesenchyme transition to collective cell migration. Dev Biol $366: 34-54$

Thomas AJ, Erickson CA. 2009. FOXD3 regulates the lineage switch between neural crest-derived glial cells and pigment cells by repressing MITF through a non-canonical mechanism. Development 136:1849-1858.

Topilko P, Schneider-Maunoury S, Levi G, Baron-Van Evercooren A, Babinet C, Charnay P. 1994. Krox-20 controls myelination in the peripheral nervous system. Nature 31:796-799.

Tuason MC, Rastikerdar A, Kuhlmann T, Goujet-Zalc C, Zalc B, Dib S, Friedman H, Peterson A. 2008. Separate proteolipid protein/DM20 enhancers serve different lineages and stages of development. J Neurosci 28:68956903.

Ulrich R, Imbschweiler I, Kalkuhl A, Lehmbecker A, Ziege S, Kegler K, Becker K, Deschl U, Wewetzer K, Baumgärtner W. 2014. Transcriptional profiling predicts overwhelming homology of schwann cells, olfactory ensheathing cells, and schwann cell-like glia. Glia 62:1559-1581.

Van Otterloo E, Cornell RA, Medeiros M, Garnett DAT. 2013. Gene regulatory evolution and the origin of macroevolutionary novelties: insights from the neural crest. Genesis 51:457-470.
Vega JA, del Valle-Soto ME, Calzada B, Alvarez-Mendez JC. 1991. Immunohistochemical localization of S-100 protein subunits (alpha and beta) in dorsal root ganglia of the rat. Cell Mol Biol 37:173-181.

Villanueva S, Glavic A, Ruiz P, Mayor R. 2002. Posteriorization by FGF, wnt, and retinoic acid is required for neural crest induction. Dev Biol 241:289-301.

Vitalis T, Alvarez C, Chen K, Shih JC, Gaspar P, Cases O. 2003. Developmental expression pattern of monoamine oxidases in sensory organs and neural crest derivatives. J Comp Neurol 464:392-403.

Wahlbuhl M, Reiprich S, Vogl MR, Bösl MR, Wegner M. 2012. Transcription factor Sox10 orchestrates activity of a neural crest-specific enhancer in the vicinity of its gene. Nucleic Acids Res 40:88-101.

Wakamatsu Y, Endo Y, Osumi O, Weston JA. 2004a. Multiple roles of SOX2, an HMG-box transcription factor in avian neural crest development. Dev Dyn 229:74-86

Wakamatsu Y, Osumi N, Weston JA. 2004b. Expression of a novel secreted factor, seraf indicates an early segregation of schwann cell precursors from neural crest during avian development. Dev Biol 268:162-173.

Wanner IB, Guerra NK, Mahoney J, Kumar A, Wood PM, Mirsky R, Jessen KR. 2006. Role of $\mathrm{N}$-cadherin in schwann cell precursors of growing nerves. Glia 54:439-459.

Wei Q, Miskimins WK, Miskimins R. 2004. Sox10 acts as a tissue-specific transcription factor enhancing activation of the myelin basic protein gene promoter by p27Kip1 and Sp1. J Neurosci Res 78:796-802.

Weider M, Küspert M, Bischof M, Vogl MR, Hornig J, Loy K, Kosian T, Müller J, Hillgärtner S, Tamm ER, Metzger D, Wegner M. 2012. Chromatin-remodeling factor Brg1 is required for schwann cell differentiation and myelination. Dev Cell 23:193-201.

Werner T, Hammer A, Wahlbuhl M, Bösl MR, Wegner M. 2007. Multiple conserved regulatory elements with overlapping functions determine Sox10 expression in mouse embryogenesis. Nucleic Acids Res 35:6526-6538.

Wilson MD, Odom DT. 2009. Evolution of transcriptional control in mammals. Curr Opin Genet Dev 19:579-585

Zarelli VE, Dawid IB. 2013. Inhibition of neural crest formation by Kctd15 involves regulation of transcription factor AP-2. Proc Natl Acad Sci USA 110: 2870-2875.

Ziegler L, Grigoryan S, Yang IH, Thakor NV, Goldstein RS. 2011. Efficient generation of schwann cells from human embryonic stem cell-derived neurospheres. Stem Cell Rev 7:394-403. 